\title{
Responses of the root rot fungus Collybia fusipes to soil
}

\section{waterlogging and oxygen availability}

\author{
C. Camy, E. Dreyer ${ }^{\star}$, C. Delatour and B. Marçais \\ Unité de Pathologie Forestière, INRA-Nancy, F54280, Champenoux, France \\ *UMR INRA UHP Ecologie-Ecophysiologie Forestières INRA-Nancy, F54280, Champenoux, France. \\ Corresponding author : Benoît Marçais, Unité de Patholo/gie Forestière, INRA-Nancy, F54280, Champenoux, \\ France. Tel : +33 383394053 ; Fax : +33 383394069 ; e-mail : marcais@nancy.inra.fr
}

Keywords : Collybia fusipes, root rot fungus, soil waterlogging, oxygen

\section{SUMMARY}

Collybia fusipes is a common root rot fungus in mature pedunculate oak forest, that causes drastic destruction of the tree root systems, especially in dry or mildly waterlogged soils. We wanted to check, under controlled conditions or in forest ecosystems, whether reduced $\mathrm{O}_{2}$ during saturation of the soil by water could interact with disease evolution. Susceptibility of waterlogged oak seedlings to $C$. fusipes was tested in a greenhouse and the survival of the pathogen in woody substrates was assessed in hydromorphic soils in a forest. A direct and detrimental effect of soil waterlogging on $C$. fusipes survival was evidenced both under controlled conditions and in forest stands. Growth of $C$. fusipes mycelium on agar media was monitored under low $\mathrm{O}_{2}$ mole fraction and compared to that of $A$. mellea and $H$. annosum. A drastic reduction in mycelial growth was evidenced in $C$. fusipes and $H$. annosum but not in $A$. mellea.

\section{INTRODUCTION}

Collybia fusipes (Bull.: Fr.) Quél is a primary parasite that causes slowly evolving root rots in various species of broadleaved trees (Delatour \& Guillaumin, 1984). In France, $C$. fusipes is common in oak forests and develops mainly at the base of mature pedunculate oaks (Quercus robur L.) (Marçais, Caël \& Delatour, 1998; Piou, Delatour \& Marçais, 2002). The distribution of the parasite in forest ecosystems and the severity of root damage induced during infection strongly depend on soil factors. Indeed, $C$. fusipes is preferentially distributed in oak forests growing on coarse textured soils (Camy et al., 2003b). This root rot pathogen was also reported to occur preferentially in dry soils (Guillaumin et al., 1985; Nanta \& Vellinga, 1995). At the stand level, temporary waterlogging in the soil is an important limiting factor for the severity of $C$. fusipes natural infection on $Q$. robur and $Q$. rubra $L$. because trees on waterlogged soils are much less prone to disease (Piou et al., 2002; Camy \& Marçais, 2002; Camy, Delatour \& Marçais, 2002a). Furthermore, the success of direct inoculation of mature oak trees was strongly reduced in waterlogged soils (Camy et al., 2003c).

Excess of water in soils results in gradual oxygen depletion. As a consequence, chemical and biological soil properties are severely affected with important consequences for the activity of soil micro-organisms and plant roots (Drew \& Lynch, 1980). Micro-organism communities shift to anaerobes and potentially toxic chemicals such as phenolic and aromatic acids or hydrogen sulfides may accumulate (Drew \& Lynch, 1980). Denitrification occurs at high rates as a consequence of soil water saturation (Grundmann \& Rolston, 1987). Thus, under field conditions, many factors related to waterlogging could interact with 
C. fusipes, and affect mycelium survival, infection and disease development. However, we hypothesised that the low frequency of presence of the pathogen in waterlogged soils, as compared to the very high frequency in coarse textured soils, could primarily result from its high susceptibility to hypoxia. An impact of oxygen availability on the survival and distribution of root rot fungi has already been mentioned by several authors. Blenis, Mulaga \& Hiratsuka (1989) observed that the survival of Armillaria ostoyae (Romagn.) Herink. on woody inocula was higher in sandy soils and related this observation to a larger oxygen availability in such soils. Production of Armillaria spp. rhizomorphs is reduced under hypoxia and their abundance decreases with the depth of soil or soil water saturation in relation to oxygen availability (Morrison, 1976; Rishbeth, 1978; Singh, 1981; Pearce et Malajczuk, 1990). Damage induced by Heterobasidion annosum also tends to be greater in soils with a high sand content and adequate aeration (Alexander, Skelly \& Morris, 1975; Froelich, Dell \& Walkinshaw, 1966). H. annosum is able to grow in the heartwood of trees, where the oxygen availability is low (Stenlid \& Redfern, 1998). However, heartwood and soil are very different environments which may explain the difference. Conflicting results have been published about the direct effect of oxygen availability on $\mathrm{H}$. annosum growth in vitro, from no effects of low oxygen (Gundersen, 1961; Lindberg, 1992) to a decrease of growth in other cases (Courtois, 1973). Decreasing $\mathrm{O}_{2}$ availability was detrimental to the decay activities of several other species of heartwood and sapwood fungi (Highley et al., 1982).

The objectives of this study were to determine, under controlled conditions and in forest ecosystems, whether the absence of $C$. fusipes in waterlogged soil could be explained by reduced $\mathrm{O}_{2}$ during soil water saturation. Susceptibility of waterlogged oak seedlings to $C$. fusipes was tested in a greenhouse and the survival of the pathogen in woody substrates was assessed in waterlogged soils in a forest. In a final step the growth of $C$. fusipes mycelium on agar media under low $\mathrm{O}_{2}$ atmospheres was measured and compared with that of $A$. mellea (Vahl.: Fr.) Kumm. and $H$. annosum (Fr.) Bref.

\section{MATERIAL AND METHODS}

\section{C. fusipes inoculum production}

Five isolates were used in the three following experiments. C. fusipes, C41, C49, C62 were isolated from $Q$. robur (south-west France, 1994), Q. rubra (central France, 1992) and Q. petraea (Matt) Liebl. (north-east France, 1994), respectively. A. mellea, M2 was isolated by J. J. Guillaumin, from Prunus persicae (South-east France, 1969). Isolate 47-R1-6 (P group) of $H$. annosum was from Pseudotsuga menziesii (north-east France, 2000).

C. fusipes inoculum was produced according to Marçais \& Delatour (1996). Briefly, stems of hazel, Corylus avellana L., $1.5-2.5 \mathrm{~cm}$ in diameter, were cut into $3 \mathrm{~cm}$ segments, placed in plastic jars and inoculated with blocks from a $C$. fusipes agar culture. Care was taken to maximise the aeration of the jars by drilling a hole in the jar top and plugging it with cotton wool. The jars were incubated at $23^{\circ} \mathrm{C}$ for $9-11$ months. These hazel segments, colonised by $C$. fusipes, were used for inoculations in experiment 1 and to assess the effects of waterlogging under field conditions in experiment 2.

$C$. fusipes, $H$. annosum and $A$. mellea isolates were used to test their mycelium growth on malt-agar under low $\mathrm{O}_{2}$ mole fraction, in experiment 3.

\section{Experiment 1: inoculation by $C$. fusipes and water-logging under controlled conditions}

Seventy-six one-year-old seedlings of pedunculate oak (Quercus robur L., northeastern France) were planted in 5 litre pots. Half of the pots were filled with a $1 / 1 \mathrm{v} / \mathrm{v}$ mix of sand and of forest soil with a clay loam texture (from Amance forest, Meurthe-et-Moselle). 
Final texture was determined in the laboratory and was $13 \%$ clay, $22 \%$ silt, $65 \%$ sand. The other half was filled with a peat / sand $1 / 2 \mathrm{v} / \mathrm{v}$ substrate. Potted seedlings were grown in a greenhouse at Champenoux, N-E France. The temperature was kept above $5^{\circ} \mathrm{C}$ during winter. Seedlings were inoculated with $C$. fusipes nine months later, in December 2000. Top soil was removed at the base of the seedlings, and the root collar was cleaned. A hazel stem segment was fastened directly against the bark with an elastic link, $2-5 \mathrm{~cm}$ below soil surface and soil was replaced. Fourteen seedlings were inoculated with isolate C41 and 22-26 with isolate C49 in each substrate. Half of the seedlings of each of the 4 categories were completely water-logged with tap water one month after inoculation (Table 1). Waterlogging was maintained during three months from January to March, and the level of the water table controlled daily, in order to induce conditions close to those encountered in forest soils. One year after inoculation, seedlings were removed from the pots and root collars and inocula were examined. Survival rate of inoculum was recorded. $C$. fusipes was assumed to have survived in the hazel stem segments whenever black crusts covered the inoculum and white mycelium was present underneath and/or when the wood had a bright orange colour. Otherwise $C$. fusipes was assumed to have disappeared from the hazel stem segment. Width and height of necrotic bark were recorded. Surface area of induced lesions was estimated from the geometric mean of these two diameters ( $\pi \times$ (height $X$ width)/4). Isolations of the fungus were attempted both from inoculum and host tissues. Tissues were washed under water, surface sterilised for $1 \mathrm{~min}$. in sodium hypochlorite (3.75\% active chlorine) and rinsed three times in sterile water. Chips of dead root collar bark or decayed wood were plated on MAT medium (10 g. $\mathrm{l}^{-1}$ of malt Difco, $15 \mathrm{~g} . \mathrm{l}^{-1}$ agar, $100 \mathrm{mg} . \mathrm{l}^{-1}$ penicillin, $100 \mathrm{mg} . \mathrm{I}^{-1}$ streptomycin and $250 \mathrm{mg}^{-\mathrm{I}^{-1}}$ thiabendazole).

An second test was set up to study survival of $C$. fusipes in hazel stem segments during waterlogging. Eight 3-litre pots were filled with the peat/sand substrate and 8 others with the soil/sand substrate. During April 2001, 2-3 hazel stem segments colonized by $C$ fusipes isolate C41 were buried in each pot 2 to $5 \mathrm{~cm}$ below soil surface (total of 47 segments). The pots were all completely flooded one month later with tap water and kept flooded in a glasshouse for 53 days. The level of the water table was checked daily. One hazel stem segment was removed from each pot at three dates: 21,35 and 53 days after flooding. Survival of the inoculum in the stem segments was recorded based on the previously described method.

\section{Experiment 2: Influence of hydromorphia on $C$. fusipes survival under field conditions}

Six oak stands located in north-eastern France, in which $C$. fusipes had been detected, were selected based on contrasting soil textures and large within-stand heterogeneity in the level of hydromorphia. In each plot a sample of soil from a depth of $30 \mathrm{~cm}$ was analysed in the laboratory for texture (\%sand). The assessment of hydromorphia severity was based on the depth of reddish traces of insoluble oxydized iron and/or discoloration indicating iron depletion, which reflects the severity of waterlogging. During January 2001, 10 hazel stem segments colonized by $C$. fusipes isolate C41 were buried in the soil of the severely hydromorphic area and 10 others in the mildly hydromorphic area of each stand. The inoculum was inserted at about $1 \mathrm{~m}$ from stem base on both sides of five trees in each area. The segments were buried below the hydromorphic soil layer in severely hydromorphic areas and above this layer in mildly hydromorphic areas. The hazel stem segments were excavated one year later and brought back to the laboratory. As a few segments could not be recovered at the end of experiment, only 8 segments were assessed per individual area in Vitrimont and 9 in the well drained area of Amance. Survival rates of $C$. fusipes inoculum were recorded as in to experiment 1. 


\section{Experiment 3: growth of $C$. fusipes, $A$. mellea and $H$. annosum under reduced oxygen mole fraction}

In vitro growth of three isolates of $C$. fusipes, one of $A$. mellea and one of $H$. annosum, was measured under different $\mathrm{O}_{2}$ mole fractions. For each isolate, a $4 \mathrm{~mm}$ malt agar disk was cut from the margin of a young colony and placed on the surface of $20 \mathrm{ml}$ solid maltagar plates. Venting ribs were present on the lower side of the Petri dishes lids in order to provide adequate $\mathrm{O} 2$ supply to the cultures. After one week for $C$. fusipes and $A$. mellea and 3 days for $H$. annosum, cultures were placed in airtight plastic jars of $50 \times 50 \times 50 \mathrm{~cm}$ filled with air mixtures differing in $\mathrm{O}_{2}$ mole fraction: $21 \%$ (normal atmospheric concentration), $8.0 \%$, $5.0 \%, 3.0 \%, 0.5 \%, 0.3 \%$ and $0.1 \%$. Target $\mathrm{O}_{2}$ mole fractions were reached by injecting $\mathrm{N}_{2}$ into the jars. $\mathrm{O}_{2}$ mole fractions were measured with a medical $\mathrm{O}_{2}$ monitor (Toptronic, model 74223 , with a resolution of $0.1 \%$ ). A little fan homogenised the atmosphere within each jar and avoided $\mathrm{CO}_{2}$ accumulation in the plates. Eight experiments were carried out. In each experiment, 2 to 3 different oxygen concentrations plus 21\% oxygen were tested (3-4 jars). Each concentration was tested 3 to 4 times. At first, 25 cultures ( 5 repetitions per isolate) per jar were preincubated for acclimation during 24 hours under the target $\mathrm{O}_{2}$ mole fraction. Then, cultures were removed and their perimeter was marked as starting point for the measurement of hyphal growth. Cultures were replaced into jars for seven days, $\mathrm{O}_{2}$ mole fractions were readjusted and controlled twice a day. After this period, cultures were removed again from jars and hyphal growth during the preceding seven days was measured.

\section{Statistical analyses}

The survival of $C$. fusipes in hazel stem segments (experiments 1 and 2) was analysed by logistic regression, using the procedure 'genmod' of SAS. The model validity was checked using the deviance/degree of freedom ratio, by plotting deviance residuals against the linear predictor and with a half-normal plot (Collett, 1991). In experiment 1, since few inocula had survived in waterlogged pots, infection success was taken into account only for control seedlings with surviving inoculum. In experiment 3 , the growth of isolates under reduced atmospheres was divided by the mean isolate growth under ambient atmosphere during the same experiment. This proportion was subjected to an analysis of variance (SAS, 1989). In the model, the isolate effect was tested as independent variable nested in the species effect.

Table 1. Results of infections after artificial inoculations by two $C$. fusipes isolates of potted $Q$. robur seedlings submitted or not to soil water logging (experiment 1)

\begin{tabular}{|c|c|c|c|c|c|}
\hline Substrate & Isolate & $\begin{array}{c}\text { Treatment } \\
\text { (seedling number) }\end{array}$ & $\begin{array}{l}\text { Number of surviving } \\
\text { inocula (\%) }\end{array}$ & $\begin{array}{l}\text { Number of seedlings } \\
\text { with bark infections }\end{array}$ & $\begin{array}{l}\text { Infected bark area } \\
\qquad\left(\mathrm{cm}^{2}\right)\end{array}$ \\
\hline \multirow{2}{*}{$\begin{array}{l}1 / 2 \text { forest soil } \\
1 / 2 \text { sand }\end{array}$} & C41 & $\begin{array}{c}\text { Control (7) } \\
\text { Waterloged (7) }\end{array}$ & $6(85.7)$ & $\begin{array}{l}3 \\
0\end{array}$ & 2.4 \\
\hline & C49 & $\begin{array}{c}\text { Control (13) } \\
\text { Waterlogged (13) }\end{array}$ & $\begin{array}{l}4(30.8) \\
0(0.0)\end{array}$ & $\begin{array}{l}0 \\
0\end{array}$ & - \\
\hline \multirow[t]{2}{*}{$\begin{array}{l}2 / 3 \text { sand } \\
1 / 3 \text { peat }^{b}\end{array}$} & C41 & $\begin{array}{c}\text { Control (7) } \\
\text { Waterlogged (7) }\end{array}$ & $\begin{array}{l}5(71.4) \\
1(14.3)\end{array}$ & $\begin{array}{l}3 \\
1\end{array}$ & $\begin{array}{l}4.39 \\
9.28\end{array}$ \\
\hline & C49 & $\begin{array}{c}\text { Control (11) } \\
\text { Waterlogged (11) }\end{array}$ & $\begin{array}{l}9(81.8) \\
0 \quad(0.0)\end{array}$ & $\begin{array}{l}5 \\
0\end{array}$ & $\begin{array}{c}3.14 \\
-\end{array}$ \\
\hline
\end{tabular}




\section{RESULTS}

\section{Experiment 1: inoculations and waterlogging under controlled conditions}

C. fusipes was isolated from all surviving inocula and all lesions. There was a severe and negative effect of waterlogging on inoculum survival independent of the growth substrate and of the $C$. fusipes isolate (Table 1). Survival was slightly higher for isolate C41 (Tables 1 and 2). After 3 months waterlogging, only one inoculum piece had survived in the soil/sand substrate and one in the peat/sand substrate. A tendency towards more seedlings with infected bark in peat/sand than in soil/sand substrate was visible (57\% and $30 \%$ respectively, Table 1). But the low number of replicates did not allow any statistical test of this observation.

Table 2. Logistic regression analysis of the relationship between inoculum survival, type of substrate (peat/sand or soil/sand), waterlogging during 3 months and fungal isolate (C41 or C49; Experiment 1).

\begin{tabular}{lcccc}
\hline Source & deviance & df & Chi-square & Pr>Chi-square \\
\hline Intercept & 45.6 & - & - & - \\
Substrate & 43.9 & 1 & 1.69 & 0.193 \\
Waterlogging & 10.9 & 1 & 33.01 & $<0.001$ \\
Isolate & 6.0 & 1 & 4.85 & 0.028 \\
Waterlogging x Substrate & 5.4 & 1 & 0.58 & 0.447 \\
Waterlogging x Isolate & 3.9 & 1 & 1.58 & 0.208 \\
\hline
\end{tabular}

During the second test, set up to follow the dynamic of $C$. fusipes survival during waterlogging, the fungus had completely disappeared from hazel stem segments after $21 \mathrm{~d}$ of water-logging since it could never be isolated from the segments after 21, 35 and 53 days of flooding, whatever the substrate.

\section{Experiment 2: influence of hydromorphia on $\mathrm{C}$. fusipes under field conditions}

The survival of $C$. fusipes after one year in hazel stem segments was independent of the sand content of soils but differed among plots (Tables 3 and 4). Survival was lower in a majority of severely hydromorphic areas in comparison with mildly hydromorphic ones. However, the interaction 'hydromorphia $x$ plot' was significant. Indeed, the survival of $C$. fusipes was high in the mildly waterlogged area in each stand. Conversely, its survival in the severely waterlogged areas was high only in Filain and Adelans (Table 2).

\section{Experiment 3: growth of $C$. fusipes, $A$. mellea and $H$. annosum under reduced oxygen mole fractions}

Under ambient $\mathrm{O}_{2}, A$. mellea, $\mathrm{C}$ fusipes and $\mathrm{H}$ annosum displayed a daily growth of $0.75 \pm 0.03 \mathrm{~mm}, 1.81 \pm 0.04 \mathrm{~mm}$ and $7.18 \pm 0.12 \mathrm{~mm}$, respectively. There was a significant effect of $\mathrm{O}_{2}$ mole fraction, species and isolates on root rot fungi growth under hypoxia in comparison with their growth under ambient atmospheres (Table 5, Fig. 1). C. fusipes growth gradually decreased when $\mathrm{O}_{2}$ mole fraction dropped below $8 \%$ and was slightly more affected than that of $\mathrm{H}$. annosum. The significant interaction between $\mathrm{O}_{2}$ mole fraction and species is mainly due to the smaller influence of hypoxia on $A$. mellea growth compared to C. fusipes and $H$. annosum (Table 5, Fig. 1). There was also a significant interaction between oxygen concentration and isolates, which could be explained by the slightly lower growth of the $C$. fusipes isolate C49 under oxygen concentrations higher than $5 \%$, in 


\section{Camy, Dreyer, Delatour and Marçais}

comparison with the two other $C$. fusipes isolates and by its slightly greater growth under concentrations lower than $0.5 \%$. When cultures of $C$. fusipes, $H$. annosum and $A$. mellea were returned to under ambient atmosphere after exposure to hypoxia the mycelium growth resumed at initial rates (results not shown).

Table 3. Main soil properties in the selected plots in $Q$. robur stands in different forests of North Eastern France and survival of $C$. fusipes on woody inocula after one year burial (experiment 2).

\begin{tabular}{|c|c|c|c|c|c|}
\hline & Plot & $\begin{array}{l}\text { Soil sand } \\
\text { content (\%) }\end{array}$ & $\begin{array}{l}\text { Depth of first traces } \\
\text { of hydromorphia }(\mathrm{cm})\end{array}$ & $\begin{array}{l}\text { Depth of hazel } \\
\text { stem segments } \\
(\mathrm{cm})\end{array}$ & $\begin{array}{l}\text { Hazel segments } \\
\text { with surviving } \\
\text { C. fusipes (\%) }\end{array}$ \\
\hline \multirow{6}{*}{$\begin{array}{l}\text { Severely } \\
\text { waterlogged } \\
\text { areas }\end{array}$} & Filain & 6.9 & 25 & 45 & 80 \\
\hline & Amance & 8.3 & 4 & 23 & 0 \\
\hline & Adelans & 17.4 & 10 & 23 & 70 \\
\hline & Mersuay & 30.4 & 5 & 27 & 0 \\
\hline & Ainvelle & 38.6 & 6 & 40 & 30 \\
\hline & Vitrimont & 41.3 & 6 & 27 & 0 \\
\hline \multirow{6}{*}{$\begin{array}{l}\text { Mildly } \\
\text { waterlogged } \\
\text { areas }\end{array}$} & Filain & 8.3 & 44 & 21 & 90 \\
\hline & Amance & 5.4 & 48 & 23 & 89 \\
\hline & Adelans & 24.2 & 48 & 20 & 90 \\
\hline & Mersuay & 34 & none until 100 & 24 & 90 \\
\hline & Ainvelle & 64.1 & 60 & 21 & 70 \\
\hline & Vitrimont & 67.5 & 58 & 20 & 100 \\
\hline
\end{tabular}

NOTE : $N=10$ inocula per plot

Table 4. Logistic regression analysis of the relationship between survival of $C$. fusipes in hazel stem segments in forest plots and soil factors (experiment 2).

\begin{tabular}{lcccc}
\hline Source & deviance & df & Chi-square & Pr>Chi-square \\
\hline intercept & 155.6 & - & - & - \\
Sand content & 155.6 & 1 & 0.00 & 0.949 \\
Plot & 120.6 & 5 & 34.94 & $<0.001$ \\
waterlogging & 90.9 & 1 & 29.67 & $<0.001$ \\
Waterlogging x plot & 72.4 & 4 & 18.50 & 0.001 \\
\hline
\end{tabular}

Table 5. Analysis of variance of the relationship between mycelium growth under low $\mathrm{O}_{2}$ and the species of root rot fungi, $C$. fusipes, $A$. mellea and $H$. annosum (experiment 3 ).

\begin{tabular}{lcrr}
\hline \multicolumn{1}{c}{ Source } & df & \multicolumn{1}{c}{$\mathrm{F}$} & \multicolumn{1}{c}{$\mathrm{p}$} \\
\hline $\mathrm{O}_{2}$ mole fraction & 1 & 406.37 & $<0.001$ \\
Species & 2 & 149.88 & $<0.001$ \\
Isolate (Species) & 2 & 3.68 & 0.026 \\
$\mathrm{O}_{2}$ mole fraction x species & 2 & 34.10 & $<0.001$ \\
$\mathrm{O}_{2}$ mole fraction x isolate (Species) & 2 & 2.88 & 0.057 \\
\hline
\end{tabular}




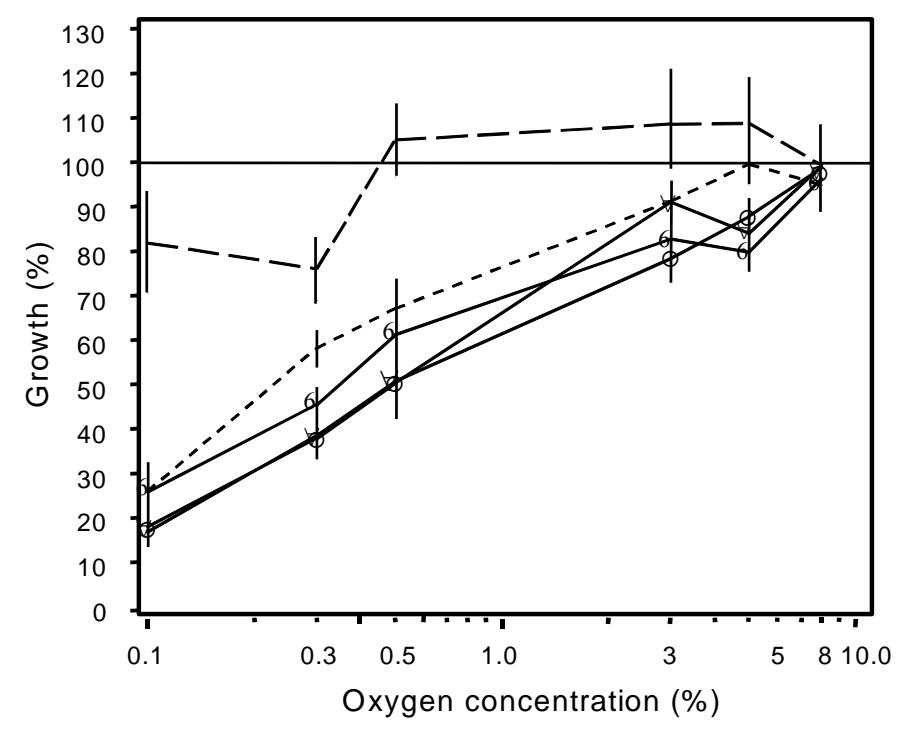

Fig. 1. growth of $A$. mellea $(---), H$. annosum (------) and C. fusipes isolates, (-*-), C41, (-6-) C49 and $(-\forall-)$ C62, under reduced oxygen mole fraction $(8,5,3,0.5,0.3$ and 0.1 $\%$ in comparison with growth of isolates at ambient atmosphere (20.9\%). The bars represent the confidential interval of the mean.

\section{DISCUSSION}

We have shown a direct and detrimental effect of soil waterlogging on $C$. fusipes survival both under controlled conditions and in forest stands. We have also demonstrated that hypoxia induced a drastic reduction of $C$. fusipes and $H$. annosum mycelial growth whereas $A$. mellea was almost insensitive.

Earlier work had shown that $C$. fusipes survival increased with soil sand content (Camy et al., 2003c). In this study, we expected the survival of $C$. fusipes in stem segments buried in forest soils to confirm this result. This was not the case, possibly due to the lower number of investigated stands (6 vs. 10) and the shorter duration of the experiment compared with the previous work ( 1 vs. 2.5 years). In these forest soils, the survival of $C$. fusipes strongly differed between severely hydromorphic areas in the different stands. C. fusipes survival in the hydromorphic areas of Filain and Adelans was high despite a relatively low soil sand content. This high survival rate might be explained by the difference of depth in hydromorphic traces which appeared slightly deeper in these 2 stands. In all studied stands, the waterlogging was mainly winter waterlogging and was induced either because the drainage of rain water was impeded by an impervious soil layer in Amance, Adelans or Filain or because of the fluctuation in the level of the alluvial groundwater in Mersuay, Ainvelle or Vitrimont. Waterlogging may be very irregular in place where it is induced by impeded drainage and was may not have been severe during the year of the experiment in Filain and Adelans, even in the so-called severely waterlogged area.

Waterlogging of inoculated seedlings allowed us to confirm under controlled conditions the direct negative effect of soil water saturation on $C$. fusipes survival in conditions close to those encountered in forest. This low ability of $C$. fusipes to survive an episode of waterlogging in the soil probably explains why natural infections are more developed in dry or mildly hydromorphic soils (Piou et al., 2002; Camy et al., 2003a). Chemical and biological properties of forest soil could not be the same than those of our pot substrates, especially in 
the peat/sand substrate. However, these difference in soil properties did not interact with waterlogging effects on $C$. fusipes survival, which was very low in the both types of substrates. This might indicate that soil water saturation is unfavorable to the pathogen mainly because it induces hypoxic conditions, although we cannot rule out other possible mechanisms such as production of toxic compounds generated during the soil waterlogging.

A high susceptibility of $C$. fusipes to hypoxia was evidenced by reduced growth of mycelium on malt-agar under hypoxia. The hypoxia induced growth reductions were completely reversible as $C$. fusipes recovered a normal growth once replaced under ambient atmosphere. Effects of soil water saturation on $C$. fusipes were more drastic, since the fungus did not survive in waterlogged soil after 21 days. This could be explained by the shorter exposure to reduced oxygen availability in the in vitro experiment (7 days versus 21 90 days) or the extremely low oxygen availability in soil water. It could also be due to the fact that $C$. fusipes in soil was possibly submitted to toxic compounds and/or competitors, much more adapted to hypoxic conditions.

The growth of $A$. mellea in vitro was slightly affected by hypoxia. This could explain the fact that $A$. mellea appears preferentially distributed in heavy soils (Termorshuizen \& Arnolds, 1994). By contrast $H$. annosum growth was strongly affected by hypoxia. Courtois (1973) found similar decreases in $H$. annosum growth under low $\mathrm{O}_{2}$. Other reports also indicate little or no influence of high hypoxia on its growth in comparable conditions (Gundersen, 1961; Lindberg, 1992).

Unfavourable effects of wood moisture content on growth of $H$. annosum had also been reported under controlled conditions (Kuhlman, 1980; Lindberg \& Johansson, 1992). Johansson \& Stenlid (1985) studied interactions between host and $H$. annosum during the initial stages of infection process in living sapwood of excised spruce roots, in watersaturated roots as well as in nitrogen atmosphere. They demonstrated a reduction in $H$. annosum mycelium growth linked with modifications of enzyme activities, dependent on oxygen supply. Cwielong \& Hüttermann (1987) demonstrated that a minimum concentration of oxygen was required for oxidation of toxic phenolic compounds, and growth of $H$. annosum was inhibited at lower $\mathrm{O}_{2}$ levels.

Furthermore, Redfern (1998) found after artificial field inoculations, a low level of infection induced by $\mathrm{H}$. annosum in peat soils and hypothesised a direct and negative effect of soil moisture and $\mathrm{pH}$ to the transfer of infection from a tree to it neighbours. Negative impact of soil water saturation under field conditions was also reported on Inonotus tomentosus (Fr.) Teng. and on A. ostoyae which incidence decreased in soils with wet moisture regimes (Bernier \& Lewis, 1999; Whitney, 1995).

The direct and negative effect of hypoxia induced by water saturation of soil on C. fusipes, demonstrated in this study, is certainly a major explanation of earlier results showing that oak trees were less frequently infected in such soil conditions (Piou et al., 2002; Camy \& Marçais, 2002; Camy et al., 2003a). Waterlogging might also influence the pathogen survival through other mechanisms such as changes in the soil micro-organism community or generation of toxic compounds. The strong susceptibility of $C$. fusipes mycelium to hypoxia might be one of the reasons why this parasite is more frequently present in coarse textured soils where oxygen availability is expected to be higher.

\section{Acknowledgments}

The authors wish to thank O.Caël and B. Bertin for their technical assistance and P. Gross and C. Brechet for their technical advice. The work reported forms part of a PhD thesis submitted to the University of Nancy by the first author and was supported by a grant from the Institut National de la Recherche Agronomique and from the region Lorraine. 


\section{References}

Alexander, S.A., Skelly, J.M. \& Morris, C.L. (1975). Edaphic factors associated with the incidence and severity of disease caused by Fomes annosus in loblolly pine plantations in Virginia. Phytopathology 65, 585-591.

Bernier, D. \& Lewis, K.J. (1999). Site and soil characteristics related to the incidence of Inonotus tomentosus. Forest Ecology and Management 120, 131-142.

Blenis, P.V., Mulaga, M.S. \& Hiratsuka, Y. (1989). Soil affects Armillaria root rot of lodgepole pine. Canadian Journal of Forest Research 19, 1638-1641.

Camy, C. \& Marçais, B. (2002). Relation between soil factors, root infection by Collybia fusipes, and tree health, in Quercus robur and Q. rubra., In Proceedings of the $10^{\text {th }}$ International conference on Root and Butt rots, Québec City, Canada, September 16-22, 2001. Ressources naturelles Canada, Service canadien des forêts, Centre de foresterie des Laurentides, rapport d'information LAU-X-126, 71-77

Camy, C., Delatour, C. \& Marçais, B. (2003a). Relationships between soil factors, Quercus robur health, Collybia fusipes root infection and Phytophthora presence. Annals of Forest Science. 60: 419-426.

Camy, C., de Villebonne, D., Delatour C. \& Marçais, B. (2003b). Soil factors associated with decline of oaks and infection by Collybia fusipes. Forest Pathology. 33: 253-266.

Camy, C., Delatour, C., Caël, O. \& Marçais, B. (2003c). Inoculation of mature pedunculate oaks (Quercus robur) with the root rot fungus Collybia fusipes and relationships with tree vigour and soil factors. European Journal of Plant Patholology. 109: 545-553.

Collett D., Modeling binary data, C. Hal.(ed), 1991, 369 pp.

Courtois, H. (1973). Einfluss von temperatur, Licht und anderen faktoren auf das mycelwachstum von Fomes annosus (Fr.) Cooke. Angewandte Botanik 47, 141-158.

Cwielong, P. \& Hüttermann, A. (1989). Biochemichal mecanisms of action of phenolic substances on Heterobasidion annosum, In Proceedings of the $7^{\text {th }}$ conference on root and butt rots of forest trees ( ed. D.J. Morrisson). pp. 208-225. Forestry Canada, Victoria, British Columbia, Canada.

Delatour, C. \& Guillaumin, J.J. (1984). Un pourridié méconnu : Collybia fusipes (Bull. ex Fr.) Quel. Compte-Rendu de l'Académie d'Agriculture de France 70, 123-126.

Drew, M.C. \& Lynch, J.M. (1980). Soil anaerobiosis, microorganisms, and root function. Annual Review of Phytopathology 18, 37-66.

Froelich, R.C., Dell, T.R. \& Walkinshaw, C.H. (1966). Soil factors associated with Fomes annosus in the Gulf States. Forest Science 12, 356-361.

Grundmann, G.L. \& Rolston, D.E. (1987). A water function approximation to degree of anaerobiosis associated with denitrification. Soil Science 144, 437-441.

Guillaumin, J.J., Bernard, C., Delatour, C. \& Belgrand, M. (1985). Contribution à l'étude du dépérissement du chêne : pathologie racinaire en forêt de Tronçais. Annales des Sciences Forestières 42, 1-22.

Gundersen K. (1961). Growth of Fomes annosus under reduced oxygen pressure and the effect of carbon dioxyde. Nature 190, 649.

Highley, T.L., Bar-Lev, S.S., Kirk, T.K. \& Larsen, M.J. (1982). Influence of $\mathrm{O}_{2}$ and $\mathrm{CO}_{2}$ on wood decay heartrot and saprot fungi. Phytopathology 73, 630-633.

Johansson, M. \& Stenlid, J. (1985). Infection of roots of Norway spruce (Picea abies) by Heterobasidion annosum. European Journal of Forest Pathology 15, 32-45.

Kuhlman, E.G. (1980). Influence of moisture on rate of decay of loblolly pine root wood by Heterobasidion annosum. Canadian Journal of Botany 58, 36-39.

Lindberg, M. (1992). S and P intersterility groups in Heterobasidion annosum; Infection frequencies through bark of Picea abies and Pinus sylvestris seedlings and in vitro growth rates at different oxygen levels. European Journal of Forest Pathology 22, 41-45.

Lindberg, M. \& Johansson, M. (1992). Resistance of Picea abies seedlings to infection by Heterobasidion annosum in relation to drought stress. European Journal Forest Pathology 22, 115-124.

Marçais, B. \& Caël, O. (2000). Comparison of the susceptibility of Quercus petraea, Q. robur and Q. rubra to Collybia fusipes. European Journal of Plant Pathology 106, 227-232. 


\section{Camy, Dreyer, Delatour and Marçais}

Marçais, B. \& Delatour, C. (1996). Inoculation of oak (Quercus robur and Q. rubra) with Collybia fusipes. Plant Disease 80, 1391-1394.

Marçais, B., Caël, O. \& Delatour, C. (1998). Investigations on the distribution and impact of Collybia fusipes in Oak forest, In Proceedings of the $9^{\text {th }}$ International Conference on Root and Butt Rots of Forest Trees. (ed. C. Delatour, J.J. Guillaumin, B. Lung-Escarmant and B. Marçais.). pp. 215222. Colloques de l'INRA n89, Paris, France.

Morrison, D.J. (1976). Vertical distribution of Armillaria mellea rhizomorphs in soil. Transaction of Britannica mycological Society 66, 393-399.

Nanta, M. \& Vellinga, E.C. (1995). Atlas van Nederlandse Paddesstoelen. A. A. Balkema, Roterdam, Brookfield pp. 352.

Pearce, M.H. \& Malajczuk, N. (1990). Factors affecting growth of Armillaria luteobubalina rhizomorphs in soil. Mycological Research 94, 38-40.

Piou, D., Delatour, C. \& Marçais, B. (2002). Hosts and distribution of Collybia fusipes in France. Forest Pathology 32, 29-41.

Rishbeth, J. (1978). Effects of soil temperature and atmosphere on growth of Armillaria rhizomorphs. Transaction of Britannica mycological Society 70, 213-220.

Redfern, D. B. (1998). The effect of soil on rot infection and spread by Heterobasidion annosum. In Proceedings of the $9^{\text {th }}$ International Conference on Root and Butt Rots of forest trees. (ed. C. Delatour, J.J. Guillaumin, B. Lung-Escarment and B. Marçais). pp. 267-273. Colloques de I'INRA n89, Paris, France.

SAS, Institute Inc. (1989). SAS / STAT user's guide, Version 6, Fourth edition, Vol I Cary

Singh, P. (1981). Armillaria mellea: growth and distribution of rhizomorphs in the forest soils of Newfoundland. European Journal of Forest Pathology 11, 208-220.

Stenlid, J. \& Redfern, D.B. (1998). Spread within the tree and stand. In Heterobasidion annosum, Biology, Ecology, Impact and Control. (ed. S. Woodward, J. Stenlid, R. Karjalainen and A. Hüttermann). pp. 125-143 CAB International, UK.

Termorshuizen, A.J. \& Arnolds, J.M. (1994). Geographical distribution of the Armillaria species in the Netherlands in relation to soil type and hosts. European Journal of Forest Pathology 24, 129136.

Whitney, R.D. (1995). Root-rotting fungi in white spruce, black spruce, and balsam fir in northern Ontario. Canadian Journal of Forest Research 25, 1209-1230. 